\title{
Analysing Long-Run and Short-Run Relationships between Macroeconomic Variables and Murabaha to the Purchase-Order: Evidence from Jordanian Islamic Bank
}

\author{
Nursilah Ahmad ${ }^{1}$, Mohamad Yazis ${ }^{1} \&$ Mohammad Salem Oudat ${ }^{1}$ \\ ${ }^{1}$ Faculty of Economics and Muamalat, Universiti Sains Islam Malaysia (USIM), Malaysia \\ Correspondence: Mohammad Salem Oudat, Faculty of Economics and Muamalat, Universiti Sains Islam \\ Malaysia (USIM), Bandar Baru Nilai, 71800 Nilai, Negeri Sembilan, Malaysia. E-mail: \\ mohammad.oudat@yahoo.com
}

Received: November 10, 2014

Accepted: November 28, 2014

Online Published: January 25, 2015

doi:10.5539/ijef.v7n2p168

URL: http://dx.doi.org/10.5539/ijef.v7n2p168

\begin{abstract}
This paper presents an empirical examination on the equilibrium relationships between macroeconomic variables (gross domestic product (GDP), foreign direct investment (FDI), and money supply (M2)) and Murabaha to the Purchase-Order (MPO), by using annual time series data for the 1978-2012 period. The Ng- Perron (2001) was applied to test the integration levels, while the bounds F-statistic test was used to examine the co-integration relationship among the variables. The autoregressive distributed lags (ARDL) approach was employed to examine long-run and short-run relationships between the variables. The results indicate that all variables are stationary at first difference and all variables are co-integrated. Further, the results of the ARDL indicate that there is a positive relationship between macroeconomic variables and MPO in long-run and short-run.
\end{abstract}

Keywords: murabaha to the purchase-order, Jordanian Islamic bank, macroeconomic variables, ARDL approach, Jordan

\section{Introduction}

An expansive body of literature has attempted to explore the relationships between stock markets and the macroeconomic variables for both developed and developing countries (AL-Sharkas, 2004; Bekhet \& Mugableh, 2012; Ratanapakorn \& Sharma, 2007; Hasing \& Hsieh, 2012). Most empirical evidence has demonstrated that there is a strong and positive nexus between economic growth and indicators of financial development (King \& Levine, 1993a, 1993b; Levine, 1997; Rajan \& Zingales, 1998).

Furthermore, there have been numerous studies that attempted to investigate the linkage between banking system and the macroeconomic variables (Deidda \& Fattouh, 2002), but there are only a handful of researches that focus on the impact of macroeconomic variables on the Islamic banks as a single entity. Therefore, to analyse the effect of some macroeconomic variables on the Islamic bank, this study tries to explore the relationship between Murabaha to the Purchase Order (MPO) as proxy of Jordan Islamic Bank (JIB), which is, represents $53 \%$ of the JIB operations (Abdul-Khaliq, 2014) and macroeconomic variables represented by Gross Domestic Product (GDP), Foreign Direct Investment (FDI) and Money Supply (M2) for the period 1978 to 2012 by employing one of the contemporaneous time series analysis techniques which is the Autoregressive Distributed Lag (ARDL) approach developed by Pesaran et al. (2001).

The main goal of this study is to ascertain if the macroeconomic variables have effect on the Islamic banking as in the stock market or not. Nonetheless, the literature showed that the stock markets have been affected by the macroeconomic variables, for instance, GDP has positive relationship with the stock market (Hasing \& Hsieh, 2012) similar to FDI that also has positive linkage with the stock market (Ali, 2014), while there is a positive relationship between M2 and stock market in the short-run but negative in the long-run (Hump \& Macmillan, 2005).

The rest of this study is organized as follows: The second section introduces the overview of the Jordanian economy and the Islamic bank. The third section presents the literature review in developed and developing countries. The fourth section reveals the methodology, models and the data used. The fifth section discusses the empirical results. The final section provides the conclusion and recommendations. 


\section{Overview of the Jordanian Economy and Islamic Bank}

Jordan is a small open country with limited natural resources. The country's economy is bogged down by deficiency of water, oil, gas, and other natural resources. Further, Jordan faces other issues such as high budget deficit, high outstanding public debt, high rates of poverty and unemployment (Central Bank of Jordan, 2013). Owing to these challenges, Jordanian economy relies heavily on external aids, labor remittances that are mostly from the Gulf countries and external debt, and with regard to the natural resources, Jordan imports oil from Iraq and gas from Egypt and recently from Qatar.

During the 1970s, the Jordanian economy recorded high growth rate and huge capital inflows as a result of the rise in the global oil prices. This has increased the demand on the Jordanian labors and indeed augmented the remittances to Jordan. However, in 1980s, Jordanian economy witnessed a recession period which was caused by a number of reasons such as the decrease in oil prices and the plummet of Jordanian dinar price from U.S. \$ (2.95)for each one Jordanian dinar in 1982 to U.S. \$ (1.73) for the same unit. The period of 1990s it was tough on Jordan's economy following the crisis in Kuwait which has caused the expulsion of Jordanian workers from Kuwait, reduction of remittances and decrease in international aid. However, Jordan's economic situation started to recover after 1999 after following and implementing the new economic policies such as the privatization of companies, signing many international agreements and global open trade. Nonetheless, in 2008 Jordan's economy was badly affected by the global financial crisis. More recently, in the end of 2010 Jordan had to face with difficult challenges caused by the political situation in the neighboring countries especially in Syria and Iraq. This had placed Jordan's economy under pressure as many refugees fled from those countries while the countries (Syria and Iraq) had stopped supplying oil and gas.

In short, since 1976 until the present time Jordan has been trying to reform the economy by implementing different polices such as privatizing, encouraging the local and foreign investments and opening the trade regime. Since that year (1976), numerous financial crises and political events have happened and affected Jordan's economy and financial system such as the Iraq war in 1991, the bombing of Amman in 2005, the Global Financial Crisis and more recently the 2011 Arab Spring that sprang up in the neighboring countries (Iraq, Egypt and Syria).

The Islamic banking in Jordan has existed for more than two decades, that is, since the establishment of the first Islamic bank in the country under name of Jordan Islamic Bank in 1978. From then on, the Bank has started to play an important role in the Jordanian financial market by contributing to different economies and social sectors with compliance with the Sharia principles and Islamic rules (Saleh \& Zeitun, 2006). Currently, JIB offers many Islamic instruments to benefit the customers and one of those principles is Murabaha to the Purchase Order.

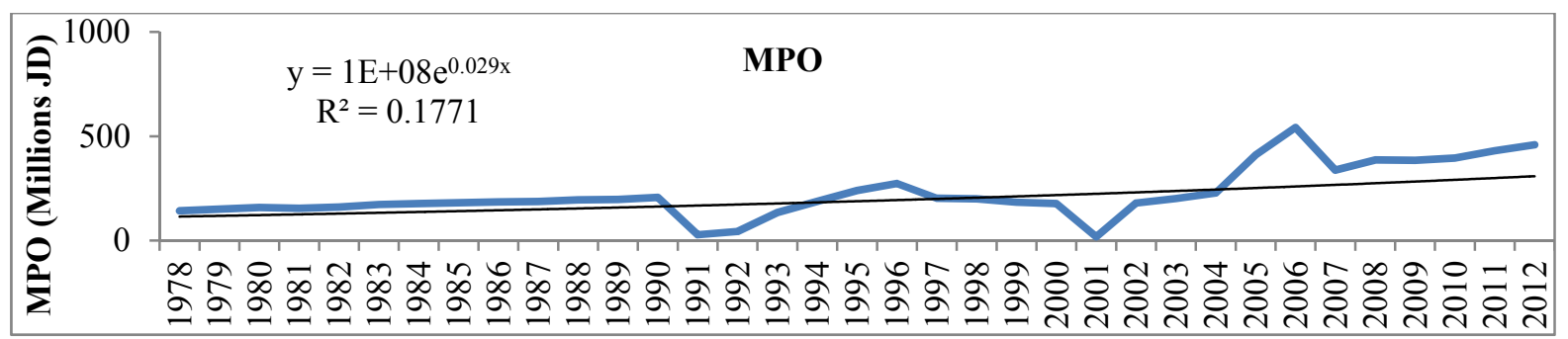

Figure 1. Murabaha to the purchase-order in Jordan for the1978-2012 period

Source: Jordan Islamic Bank for Finance and Investment, Annual Reports, 1978-2012.

Figure 1 shows that MPO had reached a yearly growth rate of 2.9\% for the 1978-2012 period and the increasing rate was notable before the global financial crisis (GFC) and during the period of Arab Spring. However, although the Islamic banks were affected by the global financial crisis and the political events, the effect differs from that of the conventional banks and stock markets that may be related to its nature assets of the Islamic banks (Kaleem, 2000). GDP is the sum of the monetary values of all final goods and services produced in the domestic economy and sold in organized market during a specified period of time, usually in a period of a year. Figure 2 reveals that the GDP has achieved an annual growth rate of $8.6 \%$ for the $1978-2012$ period. This was due to the increased number of investors during the Iraq War in 2004 and the Arab Spring in 2011, which led to the transfer of investments to Jordan as one of the most stable countries in the Middle East. 


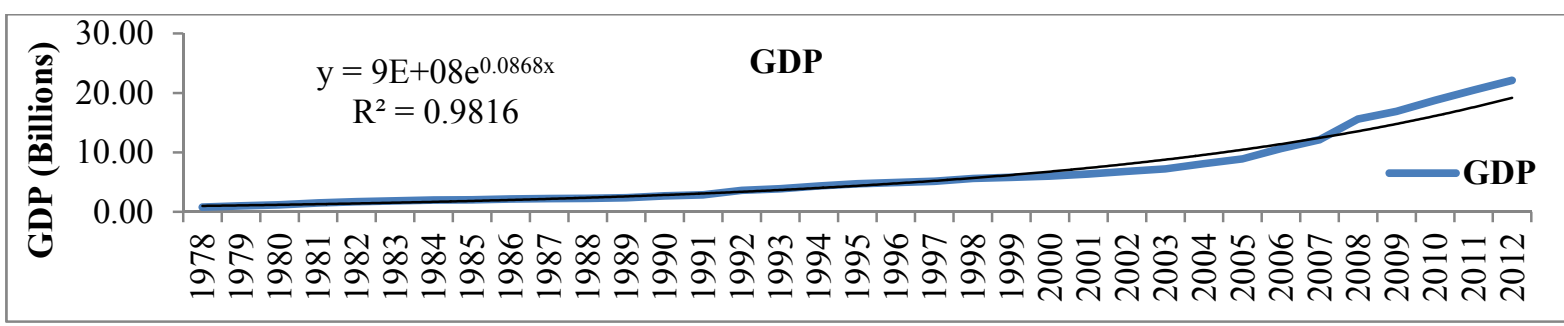

Figure 2. Gross domestic product in Jordan for the 1978-2012 period

Source: The World Bank, Jordanian Development Indicators Databases (2013) available online at: http://data.worldbank.org/country/jordan

Figure 3 represents the FDI inflows to Jordan and the figure clearly shows that there is volatility in Jordanian FDI which means that the Jordanian economy has been impacted by the global wars and financial crises that had taken place in different phases of conflicts such as the financial crisis in 1989, the Gulf War in 1991, the Asian financial crisis (AFC) in 1997, the tragedy of September 11 in 1999, the Iraqi War in 2004, the GFC in 2008 and the Arab Spring in 2010.

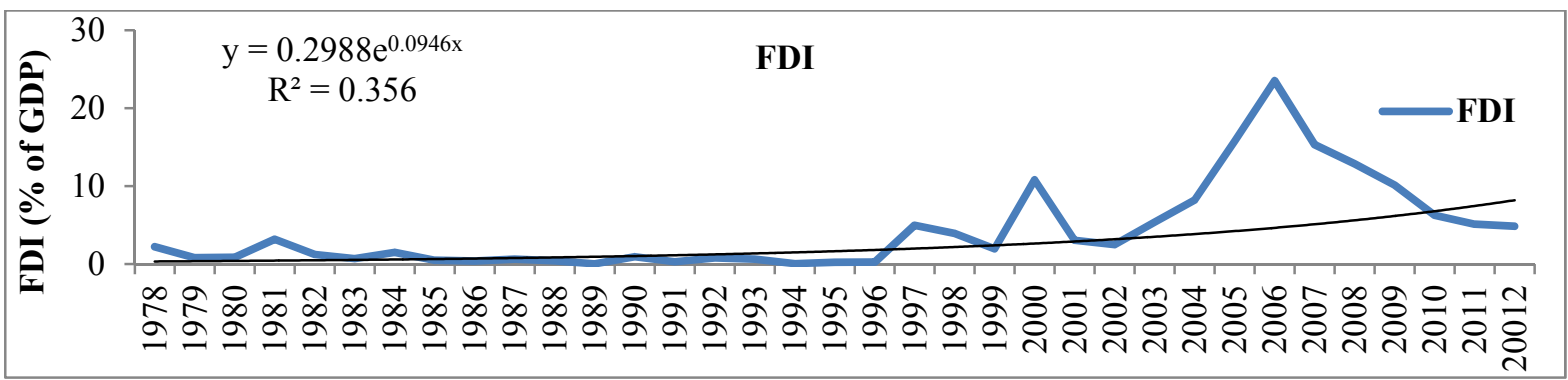

Figure 3. Foreign direct investments in Jordan for the 1978-2012 period

Source: The World Bank, Jordanian Development Indicators Databases (2013), available online at: http://data.worldbank.org/country/jordan

M2 includes all physical money, such as coins and currency, as well as demand deposits, checking accounts and Negotiable Order of Withdrawal (NOW) accounts plus savings deposits, money market mutual funds and other time deposits, which are less liquid and not as suitable as exchange mediums but can be quickly converted into cash or checking deposits.

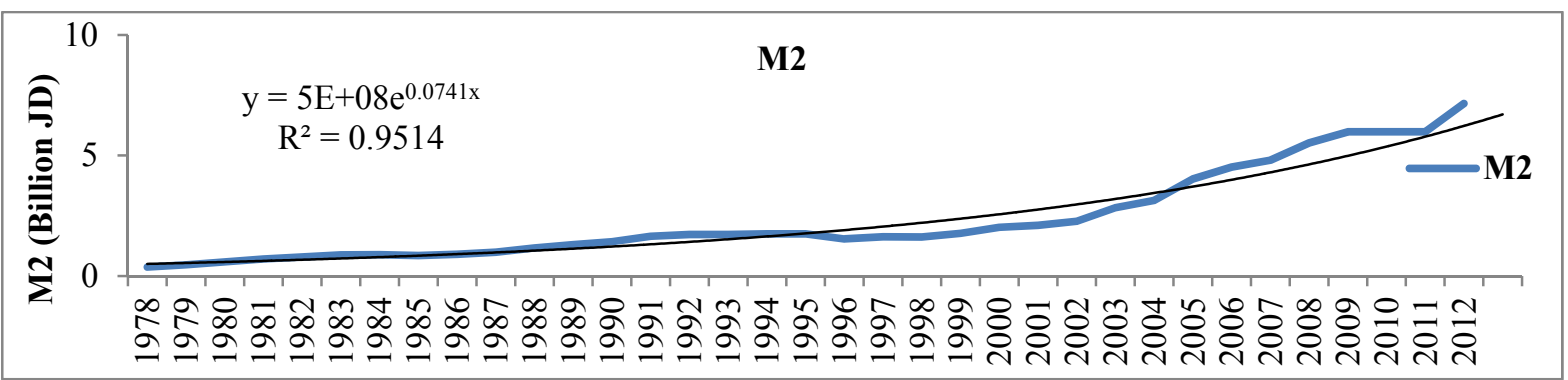

Figure 4. Money supply rate in Jordan for the 1978-2012 period

Source: The World Bank, Jordanian Development Indicators Databases (2013), available online at: http://data.worldbank.org/country/jordan

Figure 4 shows that M2 had reached a yearly growth rate of $7.4 \%$ for the 1978-2012 period. As shown in Figure 4, M2 started with a low value of JD 3.71 million in 1978 and reached the highest peak in 2012 with the value amounting to 7.15 billion. This was caused by the rising amounts of external grants from the developed countries and Gulf countries to support the Syrian refugees. Furthermore, some of these refugees had withdrawn their investments from their country and reinvested it in Jordan as they had seen it as a politically stable country in the Middle East. 


\section{Literature Review}

The link between banking and economic set has been examined since 1911 when Schumpeter tried to find the importance of the banking system on the level and growth rate of national income. Nonetheless, more discussions are needed with regard to the issue from different perspectives. Financial instruments such as credit provided by banking sector and the liabilities of the system in the economy are correlated with GDP, savings, and openness trade (Leitão, 2012). Similarly, Josephine (2009) and Plamen and Khamis (2009) argued that bank credit could help in the provision of funds to generate productive investment.

In general, many studies have been conducted in the past on the relationship between bank credit and economic growth. For instance, a study by Ibrahim (2006) showed that there was a positive relationship between GDP and bank activity because an increase in GDP will raise both supply and demand for loans. As GDP increases, banks will have more funds to make loans due to the increase in the amount of deposits. Moreover, Agrawal (2001) found that both high rate of growth of income per capita and the rapidly declining age dependency ratio have contributed to the high rate of savings in the seven Asian countries namely, South Korea, Taiwan, Singapore, Malaysia, Thailand, Indonesia and India (Haron \& Wan Azmi, 2006). Further, Deidda and Fattouh (2002) concluded that there is a positive correlation between bank-based financial development and growth of the economy in countries with higher income, and as indicated by Lakstutiene (2008), when the income of the country grows, market-based financial structures will increase. Gavin and Hausmann (1998) and the report from IMF (1993) highlight that adverse shocks in trading activity have a significant impact on the banking systems of Argentina, Chile, Colombia and Uruguay. Albeit that, studies that investigate the relationship between Islamic banking and macroeconomic variables are still very rare (Furqani \& Mulyany, 2009; Manap et al., 2012).

\section{Data and Methodology}

In this paper the annual time series data are used, which are from the 1978-2012 period. The MPO is a present of Jordan Islamic Bank (dependent variable) and three variables representing GDP, FDI and M2 (independent variables). The data gathered are from the World Bank, Jordan Central Bank, the International Monetary Fund (IMF) and the Annual Statistical Bulletins of Jordan Islamic Bank. All the time series data are transformed into logarithms. The current study analyses the equilibrium relationships among MPO and GDP, FDI and M2 in three steps. In the first step, the integration levels (stationary test) of variables are detected and $\mathrm{Ng}$ and Perron (2001) is the most popularly used for this purpose. In the second step, the Co-integration test is performed using the Bounds F-Statistics test, and in the final step, the ARDL approach is used to estimate the equilibrium relationships among variables in models. The paper has chosen the ARDL approach because it generates consistent estimates of the long-run coefficients that are asymptotically normal regardless of whether the underlying regressors are I(0), I(1) or factional integrated. In addition to that, Pesaran and Pesaran (1997) also discovered that the ARDL could be a reliable estimation and hypothesis testing tool for the long-run coefficients for a small sample in both cases where the underlying regressors are $\mathrm{I}(1)$ or $\mathrm{I}(0)$. The ARDL approach can be framed as in Equation. (1), (2), (3) and (4):

$$
\begin{gathered}
\Delta L M P O_{t}=\beta_{1+} \delta_{11} L M P O_{t-1}+\delta_{12} L G D P_{t-1}+\delta_{13} L F D I_{t-1}+\delta_{14} L M 2_{t-1}+\sum_{t=s}^{h} v_{11} \Delta L M P O_{t-s}+\sum_{t=s}^{h} v_{12} \Delta L G D P_{t-s}+ \\
\sum_{t=s}^{h} v_{13} \Delta L F D I_{t-s}+\sum_{t=s}^{h} v_{14} \Delta L M 2_{t-s}-\tau_{1} e c m_{t-1}+\varepsilon_{1 t} \\
\Delta L G D P_{t}=\beta_{2}+\delta_{21} L G D P_{t-1}+\delta_{22} L M P O_{t-1}+\delta_{23} L F D I_{t-1}+\delta_{24} L M 2_{t-1}+\sum_{t=s}^{h} v_{21} \Delta L G D P_{t-s}+\sum_{t=s}^{h} v_{22} \Delta L M P O_{t-s}+ \\
\sum_{t=s}^{h} v_{23} \Delta L F D I_{t-s}+\sum_{t=s}^{h} v_{24} \Delta L M 2_{t-s}-\tau_{2} e c m_{t-1}+\varepsilon_{2 t} \\
\Delta L F D I_{t}=\beta_{3}+\delta_{31} L F D I_{t-1}+\delta_{32} L M P O_{t-1}+\delta_{33} L G D P_{t-1}+\delta_{34} L M 2_{t-1}+\sum_{t=s}^{h} v_{31} \Delta L F D I_{t-s}+\sum_{t=s}^{h} v_{32} \Delta L M P O_{t-s}+\sum_{t=s}^{h} v_{33} \\
\Delta L G D P_{t-s}+\sum_{t=s}^{h} v_{34} \Delta L M 2_{t-s}-\tau_{3} e c m_{t-1}+\varepsilon_{3 t}
\end{gathered}
$$




$$
\begin{gathered}
\Delta L M 2_{t}=\beta_{4}+\delta_{41} L M 2_{t-1}+\delta_{42} L M P O_{t-1}+\delta_{43} L G D P_{t-1}+\delta_{44} L F D I_{t-1}+\sum_{t=s}^{h} v_{41} \Delta L M 2_{t-s}+\sum_{t=s}^{h} v_{42} \Delta L M P O_{t-s}+\sum_{t=s}^{h} v_{43} \\
\Delta L G D P_{t-s}+\sum_{t=s}^{h} v_{44} \Delta L F D I_{t-s}-\tau_{4} e c m_{t-1}+\varepsilon_{4 t}
\end{gathered}
$$

Here $\beta_{\mathrm{i}}(\mathrm{i}=1 \ldots 4)$ denotes the intercept terms. $v_{i}(\mathrm{i}=1 \ldots 4)$ represents the short-run coefficient. $\tau_{\mathrm{i}}(\mathrm{i}=1 \ldots 4)$ denotes the coefficient of error correction terms, i,e., $\left(\mathrm{ecm}_{\mathrm{t}-1}\right)_{\mathrm{s}} . \varepsilon_{\mathrm{it}}(\mathrm{i}=1 \ldots 4)$ stand for the error terms. $h$ Indicates the lag length selected using $t$ which represents the lag order. $\delta_{\mathrm{i}}(\mathrm{i}=1 \ldots 4)$ denotes the long-run coefficient.

\section{Results Analysis}

\subsection{Stationarity Test}

Table 1 presents the results of unit root test which Ng-Perron, which indicates that all series are found to be non-stationary at levels and stationary at their first differences. This means all variables are integrated for the same order, i.e. I(1). Based on these results the bounds F-statistics would be applied to test the co-integration in the next step. These results are in line with the results obtained by Mugableh (2013) who suggested the use of bounds F-statistics test if the variables are stationary at $I(1)$.

Table 1. Stationary tests results

\begin{tabular}{cccccc}
\hline \multirow{2}{*}{ Integration } & Variables & Ng- Perron test statistics & \multicolumn{3}{c}{ Ng-Perron asymptotic critical values } \\
\cline { 3 - 5 } & & & $1 \%$ & $5 \%$ & $10 \%$ \\
\hline \multirow{3}{*}{$I(1)$} & $\Delta$ LMPO & $5.63^{* *}$ & 4.03 & 5.48 & 6.67 \\
& $\Delta$ LGDP & $18.18^{* * *}$ & & & \\
& $\Delta$ LFDI & $5.56^{* *}$ & & & \\
& $\Delta$ LM2 & $233.52^{* * *}$ & & & \\
\hline
\end{tabular}

Note. (1) $* * *, * *, *$ denote statistical significance at the $1 \%, 5 \%$, and $10 \%$ levels, respectively. (2) $\Delta=$ first difference. (3) The Ng- Perron was conducted using the E-views econometric software package version 7.1.

\subsection{Co-Integration Test}

Table 2 indicates that all variables are co-integrated which means that the $\mathrm{H}_{0}$ of no co-integration among variables in the $\mathrm{LMPO}_{\mathrm{t}}, \mathrm{LGDP}_{\mathrm{t}}, \mathrm{LFDI}_{\mathrm{t}}$, and $\mathrm{LM} 2_{\mathrm{t}}$ model is rejected. On the other hand, the ordinary least squares (OLS) bound F-statistics values in the $\mathrm{LGDP}_{\mathrm{t}}$ and $\mathrm{LFDI}_{\mathrm{t}}$ models are 15.52 and 7.27 respectively, which are higher than $[\mathrm{I}(1)=5.53]$ at the $1 \%$ significance level. Meanwhile, with regard to the $\mathrm{LM} 2_{\mathrm{t}}$ model the value was 4.33, which is higher than $[\mathrm{I}(1)=4.08]$ at the $5 \%$ significance level. For $\mathrm{LMPO}_{\mathrm{t}}$ the value was 3.55 , which is higher than $[\mathrm{I}(1)=3.46]$ at the $10 \%$ significance level.

\begin{tabular}{|c|c|c|c|c|c|}
\hline \multicolumn{6}{|c|}{ Bound F-statistics critical values with Intercept } \\
\hline \multicolumn{2}{|c|}{$1 \%$ significance level } & \multicolumn{2}{|c|}{$5 \%$ significance level } & \multicolumn{2}{|c|}{$10 \%$ significance leve } \\
\hline $\mathrm{I}(0)$ & $\mathrm{I}(1)$ & $\mathrm{I}(0)$ & $\mathrm{I}(1)$ & $\mathrm{I}(0)$ & $\mathrm{I}(1)$ \\
\hline 4.09 & 5.53 & 2.94 & 4.08 & 2.46 & 3.46 \\
\hline
\end{tabular}

Table 2. Co-integration test results

OLS Bound F-statistics values:

\begin{tabular}{ccc}
\hline Models & Calculated F-statistics & Decision \\
\hline LMPO & $3.55^{*}$ & Co-integrated \\
LGDP & $15.52^{* * *}$ & Co-integrated \\
LFDI & $7.27 * * *$ & Co-integrated \\
LM2 & $4.33^{* *}$ & Co-integrated \\
\hline
\end{tabular}

Note. (1) The bound F-statistic critical values were obtained from Pesaran and Pesaran (2009, p. 544) statistical tables. (2) ***, **, * represent significance at the $1 \%, 5 \%$ and $10 \%$ levels, respectively. (3) The output of OLS Bound F-statistics values were extracted from the Micro-fit econometric software package version 4.1 . 


\subsection{Equilibrium Relationships Analysis}

Table 3 shows that $\mathrm{LGDP}_{\mathrm{t}}, \mathrm{LFDI}_{\mathrm{t}}$ and $\mathrm{LM} 2_{\mathrm{t}}$ are positively associated with the LMPOt model in long-run and short run at the $1 \%$ significance level. That is, if there is $1 \%$ increase in $\operatorname{LGDP}_{t}, \mathrm{LFDI}_{t}$ and $L M 2_{t}$, the $\mathrm{LMPO}_{\mathrm{t}}$ model increases by $0,3661 \%$, and 0 in long-run, respectively. While, in short-run are $0,121 \%$ and 0 , respectively, and vice versa.

Table 3. Equilibrium relationships analysis for the $\mathrm{LMPO}_{\mathrm{t}}$ model

\begin{tabular}{|c|c|c|c|c|c|}
\hline \multicolumn{6}{|c|}{33 observation used for estimating the long-run relationships in the $\mathrm{LMPO}_{\mathrm{t}}$ Model } \\
\hline Variables & Coefficients & Standard errors & T-ratios & P-values & Significance Levels \\
\hline Intercept term & 1.07 & 3.53 & 3.02 & 0.00 & $1 \%$ \\
\hline LGDPt-1 & 0.00 & 0.03 & 0.31 & 0.00 & $1 \%$ \\
\hline LFDIt-1 & 36.61 & 51.48 & 0.71 & 0.00 & $1 \%$ \\
\hline LM2t-1 & 0.00 & 0.02 & 0.23 & 0.00 & $1 \%$ \\
\hline \multirow{2}{*}{\multicolumn{6}{|c|}{$\begin{array}{l}33 \text { observations for estimating the short-run relationships and } \mathrm{ecm}_{\mathrm{t}-1} \text { in the } \triangle \mathrm{LMPO}_{\mathrm{t}} \text { Model } \\
\text { The selection of ARDL }(1,0,1,0) \text { approach is based on Schwarz Bayesian Criteria (SBC). }\end{array}$}} \\
\hline & & & & & \\
\hline Variables & Coefficients & Standard errors & T-ratios & P-values & Significance Levels \\
\hline Intercept term & 5.69 & 2.64 & 2.15 & 0.04 & $5 \%$ \\
\hline$\Delta \mathrm{LGDP}_{\mathrm{t}}$ & 0.00 & 0.01 & 0.31 & 0.75 & $1 \%$ \\
\hline$\Delta \mathrm{LFDI}_{\mathrm{t}}$ & 1.21 & 30.62 & 3.95 & 0.00 & $1 \%$ \\
\hline$\Delta \mathrm{LM} 2_{\mathrm{t}}$ & 0.00 & 0.01 & 0.23 & 0.00 & $1 \%$ \\
\hline $\mathrm{Ecm}_{\mathrm{t}-1}$ & -0.53 & 0.16 & -3.30 & 0.00 & $1 \%$ \\
\hline
\end{tabular}

Note. (1) Figure in parentheses represents the p-values of F-statistics. (2) Figure in brackets denotes the p-values of the chi-square $\left(\chi^{2}\right)$. (3) AIC presents Akaike information criterion that calculates the lag length and order. (4) The output was sourced from the Micro-fit econometric software package version 4.1 .

Table 4. Equilibrium relationships analysis for the $\mathrm{LGDP}_{\mathrm{t}}$ model

\begin{tabular}{|c|c|c|c|c|c|}
\hline \multicolumn{6}{|c|}{33 observation used for estimating the long-run relationships in the $\mathrm{LGDP}_{t}$ Model } \\
\hline Variables & Coefficients & Standard errors & T-ratios & P-values & Significance Levels \\
\hline Intercept term & -1.39 & 5.81 & -0.23 & 0.81 & Insignificant \\
\hline $\mathrm{LMPO}_{\mathrm{t}-1}$ & 5.54 & 4.00 & 1.38 & 0.03 & $5 \%$ \\
\hline $\mathrm{LFDI}_{\mathrm{t}-1}$ & 1.52 & 9.90 & 1.53 & 0.00 & $1 \%$ \\
\hline $\mathrm{LM} 2_{\mathrm{t}-1}$ & 0.89 & 0.08 & 11.19 & 0.00 & $1 \%$ \\
\hline \multicolumn{6}{|c|}{33 observations for estimating the short-run relationships and ecm $\mathrm{t}_{\mathrm{t}-1}$ in the $\Delta \mathrm{LGDP}_{\mathrm{t}}$ Model. } \\
\hline \multicolumn{6}{|c|}{ The selection of ARDL $(1,2,0,0)$ approach is based on SBC. } \\
\hline Variables & Coefficients & Standard errors & T-ratios & P-values & Significance Levels \\
\hline Intercept term & -2.23 & 1.71 & -1.30 & 0.02 & $5 \%$ \\
\hline$\Delta \mathrm{LMPO}_{\mathrm{t}}$ & 1.12 & 0.91 & 1.23 & 0.22 & $5 \%$ \\
\hline$\Delta \mathrm{LMPO}_{\mathrm{t}-1}$ & -3.39 & 0.85 & -3.95 & 0.00 & $1 \%$ \\
\hline$\Delta \mathrm{LFDI}_{\mathrm{t}}$ & 2.18 & 1.53 & 1.42 & 0.00 & $1 \%$ \\
\hline$\Delta \mathrm{LM} 2_{\mathrm{t}}$ & 0.17 & 0.05 & 2.88 & 0.00 & $1 \%$ \\
\hline $\mathrm{Ecm}_{\mathrm{t}-1}$ & -0.19 & 0.08 & -2.32 & 0.02 & $5 \%$ \\
\hline
\end{tabular}

Note. (1) Figure in parentheses represents the p-values of F-statistics. (2) Figure in brackets denotes the p-values of the chi-square $\left(\chi^{2}\right)$. (3) AIC presents Akaike information criterion that calculates the lag length and order. (4) The output was sourced from the Micro-fit econometric software package version 4.1 .

Table 4 presents that LFDIt and LM2t are positively associated with the LGDPt model at the $1 \%$ significance level in long-run and short-run. That is, if there is $1 \%$ increase in LFDIt , the LGDPt model increases by $152 \%$ in long-run and $218 \%$ in short-run. In addition, if there is $1 \%$ increase in LM2t, the LGDPt model increases by $89 \%$ in long-run and $17 \%$ in short run, and vice versa. Moreover, there is positive relationship between LMPOt and 
LGDPt model at the 5\% significance level in long-run and negative relationship in short-run at the $1 \%$ significance level. That is, if there is $1 \%$ increase in LMPOt, the LGDPt model increases by $554 \%$ in long-run. While, if there is decrease $1 \%$ in LMPOt in short-run, the LGDPt model increases by $339 \%$, and vice versa.

Table 5 depicts that $\mathrm{LMPO}_{\mathrm{t}}$ is positively associated with $\mathrm{LFDI}_{\mathrm{t}}$ model at the $5 \%$ significance level in the long-run and short-run. That is, if there is $1 \%$ increase in $\mathrm{LMPO}_{\mathrm{t}}$, the $\mathrm{LFDI}_{\mathrm{t}}$ model increases by $72 \%$ in long-run and $25 \%$ in short-run, and vice versa. Thus, the increase of LMPOt raises the LFDIt model in long and short run.

Table 5. Equilibrium relationships analysis for the $\mathrm{LFDI}_{\mathrm{t}}$ model

\begin{tabular}{llllll}
\hline 33 observation used for estimating the long-run relationships in the LFDI ${ }_{\mathrm{t}}$ Model \\
\hline Variables & Coefficients & Standard errors & T-ratios & P-values & Significance Levels \\
\hline Intercept term & -9.22 & 5.28 & -1.74 & 0.09 & $10 \%$ \\
LMPOt-1 & 0.72 & 0.33 & 2.18 & 0.03 & $5 \%$ \\
LGDPt-1 & 0.12 & 0.30 & 0.39 & 0.00 & $1 \%$ \\
LM2t-1 & -0.81 & 0.22 & -0.35 & 0.72 & Insignificant \\
\hline
\end{tabular}

33 observations for estimating the short-run relationships and $\mathrm{ecm}_{\mathrm{t}-1}$ in the $\Delta \mathrm{LFDI}_{\mathrm{t}}$ model.

The selection of ARDL $(1,0,0,0)$ approach is based on SBC.

\begin{tabular}{llllll}
\hline Variables & Coefficients & Standard errors & T-ratios & P-values & Significance Levels \\
\hline Intercept term & -2.13 & 1.27 & -1.67 & 0.10 & Insignificant \\
$\Delta$ LMPOt & 0.25 & 0.69 & 3.72 & 0.01 & $5 \%$ \\
$\Delta \mathrm{LGDPt}$ & -0.58 & 0.84 & -0.69 & 0.00 & $1 \%$ \\
$\Delta \mathrm{LM} 2 \mathrm{t}$ & 0.20 & 0.64 & 0.31 & 0.75 & Insignificant \\
Ecmt-1 & -0.33 & 0.12 & -2.63 & 0.01 & $1 \%$ \\
\hline
\end{tabular}

Diagnostic test: $\chi^{2}$ Autocorrelation $(1)=[0.54] ; \chi^{2}$ Heteroscedasticity $(1)=[0.60] ; \chi^{2}$ Normality $(2)=[0.23]$; $\mathrm{R}_{2}=0.40 ; \mathrm{R}_{2}=0.32 ; \mathrm{F}$-statistic $=4.81 ; \mathrm{p}$-value $=0.04$.

Note. (1) Figure in parentheses represents the p-values of F-statistics. (2) Figure in brackets denotes the p-values of the chi-square ( $\chi 2$ ). (3) AIC presents Akaike information criterion that calculates the lag length and order. (4) The output was sourced from the Micro-fit econometric software package version 4.1 .

Table 6. Equilibrium relationships analysis for the $\mathrm{LM} 2_{\mathrm{t}}$ model

\begin{tabular}{|c|c|c|c|c|c|}
\hline \multicolumn{6}{|c|}{33 observation used for estimating the long-run relationships in the $\mathrm{LM} 2_{\mathrm{t}}$ Model. } \\
\hline Variables & Coefficients & Standard errors & T-ratios & P-values & Significance Levels \\
\hline Intercept term & -3.99 & 4.46 & -0.089 & 0.92 & Insignificant \\
\hline LMPOt-1 & -2.15 & 2.46 & -0.87 & 0.39 & Insignificant \\
\hline LGDPt-1 & 1.01 & 0.10 & 9.80 & 0.00 & $1 \%$ \\
\hline LFDIt-1 & 8.06 & 5.15 & 1.56 & 0.04 & $5 \%$ \\
\hline \multicolumn{6}{|c|}{$\begin{array}{l}33 \text { observations for estimating the short-run relationships and } e^{-m_{t-1}} \text { in the } \Delta \mathrm{LFDI}_{\mathrm{t}} \text { model. } \\
\text { The selection of ARDL }(1,0,0,0) \text { approach is based on SBC. }\end{array}$} \\
\hline Variables & Coefficients & Standard errors & T-ratios & P-values & Significance Levels \\
\hline Intercept term & -1.88 & 2.14 & -0.08 & 0.93 & Insignificant \\
\hline$\Delta \mathrm{LM} 2_{\mathrm{t}-1}$ & 0.71 & 0.13 & 5.38 & 0.00 & $1 \%$ \\
\hline$\Delta \mathrm{LMPO}_{\mathrm{t}}$ & -1.01 & 1.08 & -0.94 & 0.35 & Insignificant \\
\hline$\Delta \mathrm{LGDP}_{\mathrm{t}}$ & 0.59 & 0.18 & 3.32 & 0.00 & $1 \%$ \\
\hline$\Delta \mathrm{LGDP}_{\mathrm{t}-1}$ & 0.83 & 0.19 & 4.29 & 0.00 & $1 \%$ \\
\hline$\Delta \mathrm{LFDI}_{\mathrm{t}}$ & 3.81 & 1.94 & 1.95 & 0.06 & $5 \%$ \\
\hline $\mathrm{Ecm}_{\mathrm{t}-1}$ & -0.47 & 0.12 & -3.66 & 0.00 & $1 \%$ \\
\hline
\end{tabular}

Diagnostic test: $\chi 2$ Autocorrelation $(1)=[0.47] ; \chi^{2}$ Heteroscedasticity $(1)=[0.36] ; \chi 2$ Normality $(2)=[0.23$; $\mathrm{R}_{2}=0.43 ; \mathrm{R}_{2}=0.86 ;$ F-statistic $=34.25 ; \mathrm{p}$-value $=0.00$.

Note. (1) Figure in parentheses represents the p-values of F-statistics. (2) Figure in brackets denotes the p-values of the chi-square ( $\chi^{2}$ ). (3) AIC presents Akaike information criterion that calculates the lag length and order. (4) The output was sourced from the Micro-fit econometric software package version 4.1 .

Table 5 also shows that $\mathrm{LGDP}_{\mathrm{t}}$ is positive related to the $\mathrm{LFDI}_{\mathrm{t}}$ model in long run at the $1 \%$ significance level. While, is negatively related in short-run at the $1 \%$ significance level. That is, if there is $1 \%$ increase in LGDP $_{t}$, 
the $\mathrm{LFDI}_{\mathrm{t}}$ model increases by $12 \%$ in long run. While, if there is decrease $1 \%$ in $\mathrm{LGDP}_{\mathrm{t}}$ in short-run, the $\mathrm{LFDI}_{\mathrm{t}}$ model increases by $58 \%$, and vice versa. Furthermore, there is negative associated in long between $\mathrm{LM} 2_{\mathrm{t}}$ and $\mathrm{LFDI}_{\mathrm{t}}$ model at insignificance level but there is positive associated in short-run at insignificance level.

Table 6 reviews that $\mathrm{LMPO}_{\mathrm{t}}$ is negatively associated with $\mathrm{LM}{ }_{\mathrm{t}}$ model at insignificance level in the long-run and short-run. That is, if there is $1 \%$ decrease in $\mathrm{LMPO}_{\mathrm{t}}$, the $\mathrm{LM} 2_{\mathrm{t}}$ model increases by $215 \%$ in long-run and $101 \%$ in short run, and vice versa. It is also shows that $\mathrm{LGDP}_{\mathrm{t}}$ is positively associated to the $\mathrm{LM} 2_{\mathrm{t}}$ model at $1 \%$ significance level in long-run and short-run. That is, if there is $1 \%$ increase in $\mathrm{LGDP}_{\mathrm{t}}$, the $\mathrm{LM} 2_{\mathrm{t}}$ model increases by $101 \%$ in long-run and $83 \%$ in short-run, and vice versa. Furthermore, it is shows that LFDI $_{t}$ is positively related to the $\mathrm{LM} 2{ }_{\mathrm{t}}$ model at the $5 \%$ significance level in the long-run and short-run. That is, if there is $1 \%$ increase in $\mathrm{LFDI}_{\mathrm{t}}$, the $\mathrm{LM} 2{ }_{\mathrm{t}}$ model increases by $806 \%$ in long-run and $381 \%$ in short-run, and vice versa.

\section{Conclusion and Further Study}

The current study examines the long-run and the short-run relationships between the macroeconomic variables namely GDP, FDI and M2 and MPO. The ARDL approach was used to test the co-integration and estimate the equilibrium relationships for the annual time series data from the 1978-2012 period. The results indicate that all variables are stationary at first difference and there are co-integrations among the variables. Further, the results show that there is a positive relationship between macroeconomic variables and MPO in the long-run and the short-run. These results confirmed that Jordan Islamic bank is affected by macroeconomic variables.

The paper adds to the existing literature in the field of the impact of macroeconomic variables and Islamic bank by investigating the long-run and the short-run equilibrium relationship. Also, further study could be employed to analyse empirically the relationships macroeconomic variables and conventional banks in Jordan.

\section{References}

Abdul-Khaliq, S. (2014). Comparison study of Murabaha and Istisnaa in Islamic banking in Jordan. Interdisciplinary Journal of Contemporary Research in Business, 5(9), 603-612. Retrieved from http://journal-archieves36.webs.com/603-612jan14.pdf

Agrawal, P. (2001). The relation between savings and growth co-integration and causality: Evidence from Asia. Applied Economics, 33, 499-513. http://dx.doi.org/10.1080/00036840122210

Ali, I. (2014). Impact of Foreign Direct Investment on Volatility of Stock Market: An Evidence from Pakistani Market. IOSR Journal of Business and Management (IOSR-JBM), 16(1), 77-80. http://dx.doi.org/10.9790/487X-16177780

Al-Sharkas, A. (2004). Dynamic Relationship between Macroeconomic Factors and the Jordanian Stock Market. International Journal of Applied Econometrics and Quantitative Studies, 1(1), 97-114. Retrieved from http://econpapers.repec.org/article/eaaijaeqs/v_3a1_3ay2004_3ai_3a1_5f5.htm

Beck, T., \& Levine, R. (2004). Stock market, banks, and growth: Panel evidence. Journal of Banking and Finance, 28, 423-442. http://dx.doi.org/10.3386/w9082

Beck, T., Demirguc-Kunt, A., \& Levine, R. (2000). A new database on financial development and structure. World Bank Economic Review, 14, 597-605. http://dx.doi.org/10.1093/wber/14.3.597

Beck, T., Demirguc-Kunt, A., Laeven, L., \& Levine, R. (2005). Finance, firm size and growth. World Bank Policy Research Working Paper No. 3485. http://dx.doi.org/10.1596/1813-9450-3485

Bekhet, H. A., \& Mugableh, M. I. (2012). Investigating equilibrium relationships between macroeconomic variables and Malaysian stock market index through bounds tests approach. International Journal of Economics and Finance, 4(10), 69-81. http://dx.doi.org/10.5539/ijef.v4n10p69

Central Bank of Jordan. (2013). Annual report for Amman, Jordan. Retrieved from http://www.cbj.gov.jo/pages.php?menu_id=12\&local_type $=0 \&$ local_id=0\&local_details $=0 \&$

Deidda, L., \& Fattouh, B. (2002). Non linearity between finance and growth. Economics Letters, 74, $339-345$. http://dx.doi.org/10.1111/j.1468-0351.2009.00360.x

Engle, R., \& Granger, C. (1987). Cointegration and Error Correction Representation, Estimation, and Testing. Econometrica, 55(2), 251-276. http://dx.doi.org/10.2307/1913236

Furqani, H., \& Mulyany, R. (2009). Islamic banking and economic growth: Empirical evidence from Malaysia. Journal of Economic Cooperation and Development, 30(2), 59-74. Retrieved from http://www.sesrtcic.org/files/article/308.pdf 
Gavin, M., \& Hausmann, R. (1998). The Roots of Banking Crises: The Macroeconomic Context in Banking Crises in Latin America. Working paper 318, Washington DC: Inter-American Development Bank, 1998. Retrieved from http://www.claaf.org/documents/Hausmann-roots.pdf

Harun, S., \& Azmi, W. N. W. (2006). Determinants of Islamic and Conventional Deposits in the Malaysia Banking System. Seminar School of Business, La Trobe University. Retrieved from http://www.emeraldinsight.com/doi/pdfplus/10.1108/03074350810890976

Hasing, Y., \& Hsieh, W. J. (2012). Impacts of Macroeconomic Variables on the Stock Market Index in Poland. Journal of Business and Management, 13(2), 334-343. http://dx.doi.org/10.3846/16111699.2011.620133

Humpe, A., \& Macmillan, P. D. (2005). Can macroeconomic variables explain long term stock market movements? A comparison of the US and Japan. CRIEFF Discussion Papers 0511, Centre for Research into Industry, Enterprise, Finance and the Firm.

Ibrahim, M. H. (2006). Stock prices and bank loan dynamics in a developing country: the case of Malaysia. Journal of Applied Economics, 9(1), 71-89. Retrieved from http://papers.ssrn.com/sol3/papers.cfm?abstract_id=908666

International Monetary Fund. (1993). International Capital Markets, Part II: Systemic Issues in International Finance. Retrieved from http://books.google.com.my/books?id=GTKwm0XW7mMC\&pg=PP1\&lpg=PP1\&dq=International+Monet ary+Fund+1993.+International+Capital+Markets, +Part+II:+Systemic+Issues+in+International+Finance.\&s ource=bl\&ots=8-KBTaQuv5\&sig=LL6gztpthDZkjVoYkm0CHIiZrkw\&hl=ar\&sa=X\&ei=gZtyVIfVFIXJuA T5-ICQCw\&ved=0CBwQ6AEwAA\#v=onepage\&q=International\%20Monetary\%20Fund\%201993.\%20Int ernational $\% 20$ Capital $\% 20$ Markets $\% 2 \mathrm{C} \% 20$ Part $\% 20 \mathrm{II} \% 3 \mathrm{~A} \% 20$ Systemic $\% 20$ Issues $\% 20 \mathrm{in} \% 20$ International $\% 20$ Finance. $\& \mathrm{f}=$ false

Josephine, N. O. (2009). Analysis of Bank Credit on the Nigerian Economic Growth (1992-2008). Jos Journal of Economics, 4(1), 43-58. $\quad$ Retrieved http://www.docstoc.com/docs/145262790/An-Analysis-of-Banks-Credit-on-the-Nigerian-Economic-Growt h_1

Kaleem, A. (2000). Modeling Monetary Stability under Dual Banking System: The case of Malaysia. International Journal of Islamic Financial Services, 2(1), 21-42. Retrieved from http://www.iiibf.org/journal.html

King, R., \& Levine, R. (1993a). Finance, Entrepreneurship and Growth: Theory and Evidence. Journal of Monetary Economics, 32(3), 523-542. http://dx.doi.org/10.1016/0304-3932(93)90028-E

King, R., \& Levine, R. (1993b). Finance and Growth: Schumpeter Might be Right. Quarterly Journal of Economics, 108(3),717-737. Retrieved from http://dx.doi.org/10.2307/2118406

Lakstutiene, A. (2008). Correlation of the Indicators of the Financial System and Gross Domestic Product in European Union Countries. Engineering Economics, (3), 7-18. Retrieved from http://www.ktu.lt/lt/mokslas/zurnalai/inzeko/58/1392-2758-2008-3-58-07.pdf

Leitão, N. C. (2012). Bank credit and economic growth. MPRA Munich Personal RePEc Archive. http://mpra.ub.uni-muenchen.de/42664/MPRA Paper No. 42664

Levine, R. (1997). Financial development and economic growth: Views and agenda. Journal of Economic Literature, 35(2), 688-726. Retrieved from https://ideas.repec.org/a/aea/jeclit/v35y1997i2p688-726.html

Levine, R., Loayza, N., \& Beck, T. (2000). Financial Intermediation and Growth: Causality and Cause. Journal of Monetary Econmics, 46, 31-77. https://ideas.repec.org/a/eee/moneco/v46y2000i1p31-77.html

Manap, T. A. A., Abduh, M., \& Omar, M. A. (2012). Islamic Banking-Growth Nexus: Evidence from Toda-Yamamoto and Bootstrap Granger Causality Test. Journal of Islamic Finance, 1(1), 59-66. Retrieved from http://journals.iium.edu.my/iiibf-journal/index.php/jif/article/view/5/5

Mugableh, M. I. (2013). Analysing the $\mathrm{CO}_{2}$ emissions function in Malaysia: Autoregressive distributed lag approach. Procedia Economics and Finance, 5, 571-580. http://dx.doi.org/10.1016/S2212-5671(13)00067-1

Ng, S., \& Perron, P. (2001). LAG Length Selection and the Construction of Unit Root Tests with Good Size and Power. Econometrica, 69(6), 1519-1554. http://dx.doi.org/10.1111/1468-0262.00256

Pesaran, M. H., \& Pesaran, B. (1997). Working with Micro-fit 4.0: An interactive econometric software package 
(DOS and Windows versions). Oxford University Press, Oxford. http://rove.nla.gov.au/work/7618564?q=+\&versionId=8777284

Pesaran, M. H., Shin, Y., \& Smith, R. J. (2001). Bounds testing approach to the analysis of level relationships. Journal of Applied Econometrics, 16(3), 289-326. http://dx.doi.org/10.1002/jae.616

Plamen, I., \& Khamis, M. (2009). Credit Growth in Sub-Saharan Africa-Sources, Risks, and Policy Responses. International Monetary Fund Working Paper, WP/09/180. Retrieved from http://www.imf.org/external/pubs/ft/wp/2009/wp09180.pdf

Rajan, R., \& Zingales, L. (1998). Financial Dependence and Growth. American Economic Review, 88(3), 559586. http://dx.doi.org/10.3386/w5758

Ratanapakorn, O., \& Sharma, S. (2007). Dynamic Analysis between the U.S. Stock Returns and the Macroeconomic Variables. Applied Financial Economics, 17(5), 369-377. http://dx.doi.org/10.1080/09603100600638944

Saleh, A. S., \& Zeitun, R. (2006). Islamic Banking Performance in the Middle East: A Case Study in Jordan. University of Wollongong Research Online, Faculty of Business- Economics Working Paper, 06-21. Retrieved from http://www.researchgate.net/publication/23694733

Schumpeter, J. A. (1911). The Theory of Economic Development. Translated by Redvers Opie. Cambridge MA: Harvard University Press. $\quad$ Retrieved http://books.google.com.my/books?hl=en\&lr=\&id=-OZwWcOGeOwC\&oi=fnd\&pg=PR6\&dq=The+Theor $\mathrm{y}+\mathrm{of}+$ Economic + Development, $+\% 28$ translated + by + Redvers + Opie $\% 29+\% 28$ Cambridge + MA: + Harvard $+\mathrm{U}$ niversity+Press, $+1934 \% 29 . \&$ ots=iM4Ys4zaJg\&sig=-sgs9L 78DAIOoaQKn4NVnHqZ0rc\#v=onepage\&q\&f $=$ false

\section{Copyrights}

Copyright for this article is retained by the author(s), with first publication rights granted to the journal.

This is an open-access article distributed under the terms and conditions of the Creative Commons Attribution license (http://creativecommons.org/licenses/by/3.0/). 